\title{
Floristic Composition AND GROWTH OF WeEdS UNDER CUSTARD Apple (Annona squamosa) Progenies ${ }^{1}$
}

\author{
Composição Florística e Crescimento de Plantas Daninhas sob a Copa de Progênies de \\ Fruta-do-Conde (Annona squamosa)
}

\author{
SILVA, P.S.L. ${ }^{2}$, BARBOSA, Z. ${ }^{3}$, OLIVEIRA, O.F..$^{4}$, ANTONIO, R.P. ${ }^{5}$ e SILVA, P.I.B. ${ }^{5}$
}

\begin{abstract}
Weeds have a negative influence on several fruit tree characteristics, such as yield, making it difficult to management practices in orchards. Alternative weed management methods, aiming to reduce the use of herbicides, have become attractive since herbicides are costly and cause environmental degradation. The use of cultivars with greater competitive ability against weeds has attracted international attention. The objective of this work was to evaluate the floristic composition and growth of weeds under the canopies of irrigated custard apple tree progenies. Twenty half-sibling progenies around three years of age were evaluated in a random block design with five replicates and four plants per plot. A circle with a $0.5 \mathrm{~m}^{2}$ area was established around the trunk of each plant. Floristic composition, fresh matter, and dry matter mass of the above-ground part of the weeds, were evaluated in this area. Root collar and canopy diameters, as well as leaf area of the progenies were also evaluated. Fifty-eight weed species were recorded. The five weed families with the most species were Leguminosae, Convolvulaceae, Euphorbiaceae, Malvaceae and Sterculiaceae, in decreasing order. The number of weed species per plot ranged from 6 to 18, but there was no difference between the mean percentages of different weeds under the canopies of the progenies. The lowest weed fresh and dry matter masses occurred in progenies JG1 and SM8, respectively. There were no differences between progenies with regard to root collar diameter and leaf area; however, one of the lowest weed dry matter yields was observed under the canopy of progeny FE4, which showed the largest canopy diameter.
\end{abstract}

Key words: Annona squamosa, custard apple fruit, weeds.

RESUMO - As plantas daninhas (PD) afetam várias características das fruteiras, inclusive o rendimento, e podem dificultar a execução de tratos culturais nos pomares. Existe interesse em métodos alternativos de manejo das PD, visando reduzir o uso de herbicidas, que são caros e causam degradação ambiental. Dentre esses métodos, a adoção de cultivares com maior habilidade competitiva com as PD tem despertado atenção internacional. $\mathrm{O}$ objetivo do trabalho foi avaliar a composição florística e o crescimento de PD sob a copa de progênies de pinheira irrigadas. Vinte progênies de meias-irmãs, com idade aproximada de três anos, foram avaliadas no delineamento de blocos ao acaso, com cinco repetições e quatro plantas por parcela. Ao redor do caule de cada planta estabeleceu-se um círculo com área de 0,5 $\mathrm{m}^{2}$. Nessa área, foram avaliadas a composição e as massas das matérias fresca e seca da parte aérea das PD. Avaliaram-se também os diâmetros do colo e da copa e a área da folha das progênies. Ocorreram 58 espécies de PD. As famílias com maior número de espécies, em ordem decrescente, foram Leguminosae, Convolvulaceae, Euphorbiaceae, Malvaceae e Sterculiaceae. O número de espécies de $\mathrm{PD} /$ parcela variou de 6 a 18, porém não houve diferença entre a porcentagem média de diferentes PD sob a copa das progênies. As menores massas de matérias fresca e seca de PD ocorreram nas progênies JG1 e SM8, respectivamente. Não houve diferenças entre progênies quanto a diâmetro do colo e área foliar, mas sob a copa da progênie FE4, que apresentou o maior diâmetro da copa, observou-se um dos menores rendimentos de matéria seca de $\mathrm{PD}$.

Palavras-chave: Annona squamosa, fruta-do-conde, invasoras.

Recebido para publicação em 19.3.2004 e na forma revisada em 17.12.2004.

Trabalho financiado parcialmente pela FINEP.

2 Professor Adjunto, Bolsista do CNPq, Escola Superior de Agricultura de Mossoró - ESAM, BR 110, km 47, Bairro Pres. Costa e Silva, 59625-900 Mossoró-RN, <paulosergio@esam.br>. ${ }^{3}$ Professora Substituta, Universidade do Vale do Jaguaribe; ${ }^{4}$ Professor Adjunto, ESAM; ${ }^{5}$ Estudante de agronomia da ESAM. 


\section{INTRODUCTION}

Irrigated fruit cropping is today one of the most important agricultural activities in Mossoró-Assu Agripole, Rio Grande do Norte, with melon (Cucumis melo) being the predominant crop. However, fruit growers have been showing an increasing interest in the cultivation of new species for several reasons: Melon plants are generally grown in the second semester and farmers are interested in retaining the laborers hired to work on the crop; monoculture is causing serious diseases and pest problems, and the importing markets are interested in a greater variety of tropical fruits.

Custard apple plant (Annona squamosa) is a many branched-out tree, 4 to $6 \mathrm{~m}$ in height. Its leaves are deciduous, with oblong-elliptical blades 5 to $15 \mathrm{~cm}$ long and 2 to $6 \mathrm{~cm}$ wide. The fruit is a round, ovoid, spherical, or cordiform syncarp, 5 to $10 \mathrm{~cm}$ in diameter. The pulp is fragrant, with a very sweet pleasant flavor (São José et al., 1997). Custard apple tree is cultivated in several Northeastern states in Brazil, including Alagoas, Ceará, Paraíba, Pernambuco and Rio Grande do Norte, as well as in states in other regions, such as Minas Gerais, Rio de Janeiro and São Paulo (São José et al., 1997).

Studies on weeds in perennial crops have been conducted for several species, including forest species (Toledo et al., 2000a, b), fruit trees (Carvalho et al., 1993; Senarathne et al., 2003; Souza et al., 2003; Yanagizawa \& Maimoni-Rodella, 1999), and other types of crops (Aguilar et al., 2003; Ronchi et al., 2003; Santa-Cecília et al., 1997; DeFrank \& Clement, 1995). Such studies have evaluated the floristic composition of weeds (Souza et al., 2003; Yanagizawa \& Maimoni-Rodella, 1999), their influence on nutrient accumulation by the crop (Ronchi et al., 2003), the incidence of pests (Santa-Cecilia et al., 1997), initial plant development (Toledo et al., 2000a, b) and their effect on crop yield (Carvalho et al., 1993; DeFrank \& Clement, 1995; Senarathne et al., 2003). When not controlled, weeds reduce the initial growth of perennial plants, negatively influencing stem diameter and height (Toledo et al., 2000a, b), nutrient content (Ronchi et al., 2003) and crop yield (Carvalho et al.,
1993; Senarathne et al., 2003). In orchards, weeds cause additional problems since operations such as pruning, fertilization, and fruit harvesting and collecting sometimes become more difficult (Senarathne et al., 2003). No papers on the influence of weeds on custard apple trees have been found in the literature. However, since weeds in general reduce crop yields, including fruit trees (Carvalho et al., 1993; Senarathne et al., 2003), they must be a serious problem for custard apple trees in the region where the work was conducted.

The objective of this work was to evaluate the floristic composition and growth of weeds under the canopies of irrigated custard apple tree progenies.

\section{MATERIAL AND METHODS}

The experiment was conducted at the "Rafael Fernandes" Experimental Farm (latitude $5^{\circ} 11^{\prime} \mathrm{S}$, longitude $37^{\circ} 20^{\prime} \mathrm{W}$ and altitude $18 \mathrm{~m}$ ), in Mossoró, Rio Grande do Norte, Brazil. The mean maximum temperature in the region is between 32.1 and $34.5{ }^{\circ} \mathrm{C}$ and the minimum is between 21.3 and $23.7^{\circ} \mathrm{C}$, with June and July as the coolest months. In view of the low latitude, the mean temperature does not present great annual variations. Since the region is located between 500 and $700 \mathrm{~mm}$ isohyets, climate, according to W. Köppen's classification, is ranked as type BSwh', i. e., very hot, with a summer rainy season that extends through the fall. Mean annual evapotranspiration is around $2000 \mathrm{~mm}$ and mean insolation is 236 hours per month, with the driest months also being the months with the least insolation. Relative humidity is between 60.5 and $79.1 \%$ and mean monthly wind speed ranges between 2.6 and $5.6 \mathrm{~m} \mathrm{~s}^{-1}$ (Carmo Filho \& Oliveira, 1989).

The area of the experiment was first planted with jojoba (Simmondsia chinensis), which 1990, after three years was eliminated, and the area was maintained untouched since then. Therefore, the weeds evaluated in the present work apparently occurred spontaneously in the experimental area and not due to the treatments (progenies) evaluated. The experimental soil was 
classified according to the Brazilian Soil Classification System as Red-Yellow Eutrophic Podzolic (EMBRAPA, 1999) and as Ferric Lixisol according to the Soil Map of the World (FAO, 1988).

The progenies were obtained in home orchards in the municipal districts of AracatiCE, Mossoró-RN, and Serra do Mel-RN. Based on plant health and vigor and apparent fruit yield, 25 matrices were selected. Six fruits were removed from each matrix to provide seeds for seedling production. The seeds were sown in perforated black plastic bags, $32 \mathrm{~cm}$ in length and $25 \mathrm{~cm}$ in diameter. The bags were filled with a substrate consisting of $1,800 \mathrm{~L}$ cattle manure, 3,600 L Red-Yellow Argisol (RYA), $1,080 \mathrm{~g}$ potassium chloride and 1,620 g single superphosphate. At 23 and 25 days after sowing, the seedlings were applied the product Mastermins (which contains, as percentages: $14 \mathrm{~N}, 9 \mathrm{P}_{2} \mathrm{O}_{5}, 6 \mathrm{~K}_{2} \mathrm{O}, 08 \mathrm{~S}, 1.5 \mathrm{Mg}, 2 \mathrm{Zn}, 0.1 \mathrm{~B}$, $1.5 \mathrm{Mn}$ and $0.05 \mathrm{Mo}$ ). Among the 25 progenies, 20 were selected based on their vigor.

The pits were opened in October/2000, measuring $60 \mathrm{~cm} \times 60 \mathrm{~cm} \times 60 \mathrm{~cm}$, at a row spacing of $5.0 \mathrm{~m} \times 4.5 \mathrm{~m}$. Eighteen liters of cattle manure, in addition to $240 \mathrm{~g}$ ammonium sulfate $\left(80 \mathrm{~kg} \mathrm{~N} \mathrm{ha}^{-1}\right), 2,340 \mathrm{~g}$ single superphosphate $\left(80 \mathrm{~kg} \mathrm{P}_{2} \mathrm{O}_{5} \mathrm{ha}^{-1}\right)$ and $60 \mathrm{~g}$ potassium chloride $\left(60 \mathrm{~kg} \mathrm{~K}_{2} \mathrm{O}^{5} \mathrm{ha}^{-1}\right)$ per pit were used as fertilizer. Fertilization, except for manure, was repeated on the $20^{\text {th }}$ of February, April, June, August and October, 2001 and 2002.

The progenies were evaluated on a randomized block design with five replicates and four plants per plot, irrigated with a microsprinkler system. Each custard apple tree was associated with a sprinkler placed near the stem base, with a flow of approximately $50 \mathrm{~L} \mathrm{~h}^{-1}$. Each plant received about 100 liters of water, three days a week. Due to water limitations, a greater amount of water could not be applied. In November 2003, approximately 100 days after, a weeding operation was performed to rid the custard apple trees of weeds. All the custard apple trees (400 plants) were evaluated for root collar diameter (with a digital caliper rule, on two perpendicular directions), canopy diameter (with a measuring tape, on two perpendicular directions) and leaf area (of five adult leaves randomly gathered at the median third portion of the plant height, using an integrator LI-COR model LI-3100, USA). Also, a circle with an approximate area of $0.5 \mathrm{~m}^{2}$ was established around the trunk of each plant. The area from which weeds were collected under each custard apple tree measured $0.5 \mathrm{~m}^{2}$, and it is apparently a small sampling area. It represents approximately $12 \%$ of the area occupied by each progeny, i.e., $3 \%$ of the area occupied by each of the four plants in each plot. However, the progenies were irrigated by micro-sprinkling, which comprised an area of about $3.14 \mathrm{~m}^{2}$ (in which the occurrence of weeds was possible). In this case, weed collection area $\left(0.5 \mathrm{~m}^{2}\right)$ corresponded to almost $16 \%$ being irrigated around each progeny. It must also be mentioned that increasing the sampled area could make harvest, separation, weighing, and daily drying of larger amounts of weeds in 20 progenies of a same block an impracticable undertaking. The weeds within this area were cut at ground level, weighed, identified, and placed in a forced air circulation oven at a temperature of $70-80{ }^{\circ} \mathrm{C}$ for dry mass evaluation. The mean values for root collar, canopy diameter, and leaf area of the four custard apple trees in the plot were used in the analysis of variance. A three-year interval elapsed from custard apple tree planting until the time this work was conducted. Although there was an interest in evaluating the occurrence of weeds at least once every year - which would allow for weedoccurrence curves to be fitted - the evaluation upon which this work was based was only carried out once.

The data for the evaluated characteristics were assessed by analysis of variance. The ratio of number of species in each progeny to total number of species in the experimental area were transformed to arc $\sin \sqrt{ } p$ before analysis of variance, since it is a well-known fact that proportions tend to follow a binomial, rather than a normal distribution (Zar, 1999). The coefficient of linear correlation between custard apple characteristics and weed characteristics was also estimated (Gomez \& Gomez, 1984). The statistical analyses were performed using software developed by Universidade Federal de Viçosa (Ribeiro Júnior, 2001).

Planta Daninha, Viçosa-MG, v. 22, n. 4, p. 529-537, 2004 


\section{RESULTS AND DISCUSSION}

The frequency (number of plots where the weed occurred/total number of plots) of weed species ranged from $1 \%$ to $90 \%$ (Table 1 ). Of the 58 species observed, the most frequent were Amaranthus viridis (80\%), Herissantia crispa (75\%), Ipomoea bahiensis (89\%), Mimosa quadrivalis (DC) Barneby (90\%) and Mollugo verticillata (87\%), which occurred in, at least, $75 \%$ of the plots, distributed throughout the experimental field. The weed families with the most number of species were Leguminosae, Convolvulaceae, Euphorbiaceae, Malvaceae and Sterculiaceae, in this order.

A wide variability also occurred in number and type of species associated with each plot
(Table 2). For example, only six species occurred in plot 5 of block 1 , and in plots 2 and 15 of block 2, but only Amaranthus viridis and Mimosa quadrivalis (DC) Barneby occurred simultaneously in these three plots. Eighteen species occurred in plot 11 of block 3 .

The richness (Table 1 ) and distribution (Table 2) of weeds occurring in a given agricultural area probably depend on three factors, with interactions among them: the environment, the crop being explored, and the weeds themselves. This distinction into three groups of factors makes sense only for purposes of discussion, since from the weed point of view obviously a greater or smaller number of factors can be considered as being part of the environment. It must be borne in mind that

Tabela 1 - Frequency (number of plots where at least one plant of the species/100 plots has occurred) of weeds in custard apple tree plots

\begin{tabular}{|c|c|c|c|c|c|c|c|}
\hline $\begin{array}{c}\text { Order } \\
\text { no. }\end{array}$ & Species & Family & $\begin{array}{c}\text { Frequency } \\
(\%)\end{array}$ & $\begin{array}{c}\text { Order } \\
\text { no. }\end{array}$ & Species & Family & $\begin{array}{l}\text { Frequency } \\
(\%)\end{array}$ \\
\hline 1 & Adenocalymma sp. & Bignoniaceae & 36 & 30 & Indigofera $\mathrm{sp}$. & Leg. Faboideae & 2 \\
\hline 2 & $\begin{array}{l}\text { Althernantera ficoidea (L.) P. } \\
\text { Beauv. }\end{array}$ & Amaranthaceae & 3 & 31 & Ipomoea asarifolia (Desr.) Roem. \& Schult & Convolvulaceae & 1 \\
\hline 3 & Amaranthus viridis $\mathrm{L}$. & Amaranthaceae & 80 & 32 & Ipomoea bahiensis Willd. ex Roem. \& Schult & Convolvulaceae & 89 \\
\hline 4 & Aniseia gracillima Choisy & Convolvulaceae & 2 & 33 & Jacquemontia sp. & Convolvulaceae & 45 \\
\hline 5 & Blainvillea $\mathrm{sp}$. & Compositae & 6 & 34 & Macropitilium atropurpureum (DC.) Urb. & Leg. Faboideae & 20 \\
\hline 6 & Boerhavia diffusa $\mathrm{L}$. & Nyctaginaceae & 32 & 35 & Manihot glaziovii Muell. Arg. & Euphorbiaceae & 1 \\
\hline 7 & Borreria verticilata G.F.W. Mey & Rubiaceae & 37 & 36 & Melochia piramidata $\mathrm{L}$. & Sterculiaceae & 6 \\
\hline 8 & Capparis flexuosa $\mathrm{L}$. & Capparidaceae & 1 & 37 & Merremia aegyptia $(\mathrm{L})$. & Convolvulaceae & 2 \\
\hline 9 & $\begin{array}{l}\text { Carnavalia brasiliensis Mart. ex } \\
\text { Benth. }\end{array}$ & Leg. Faboideae & 11 & 38 & Microtea paniculata Moq. & Phytolaccaceae & 4 \\
\hline 10 & Cenchrus echinatus $\mathrm{L}$. & Gramineae & 58 & 39 & Mimosa modesta Mart. & "'Leg. Mimosoideae" & 4 \\
\hline 11 & Centrosema brasilianunn Benth & Leg. Faboideae & 43 & 40 & Mimosa quadrivalis (DC) Barneby & Leg. Mimosoideae & 90 \\
\hline 12 & Chaetocalyx sp. & Leg. Faboideae & 3 & 41 & Mollugo verticillata $\mathrm{L}$.' & Molluginaceae & 87 \\
\hline 13 & Chloris virgata $\mathrm{Sw}$. & Gramineae & 1 & 42 & Neojobertia brasiliensis Baill. & Bignoniaceae & 4 \\
\hline 14 & Commelina sp. & Commelinaceae & 12 & 43 & Passiflora foetida $\mathrm{L}$. & Passifloraceae & 4 \\
\hline 15 & Corchorus argutus H.B.K. & Tiliaceae & 14 & 44 & Portulaca mucronata Link. & Portulacaceae & 7 \\
\hline 16 & Corchorus hirtus L. & Tiliaceae & 2 & 45 & Rhynchelythrum repens (Willd.) C.E. Hubb. & Gramineae & 1 \\
\hline 17 & Croton glandulosus $\mathrm{L}$. & Euphorbiaceae & 11 & 46 & $\begin{array}{l}\text { Richardia grandiflora (Cham. \& Schlecht.) } \\
\text { Steudel }\end{array}$ & Rubiaceae & 2 \\
\hline 18 & Croton lobatus $\mathrm{L}$. & Euphorbiaceae & 3 & 47 & Scoparia dulcis L. & Scrophulariaceae & 1 \\
\hline 19 & $\begin{array}{l}\text { Dactyloctenium aegyptium (L.) } \\
\text { K. Richt. }\end{array}$ & Gramineae & 19 & 48 & Senna pilifera (Vogel) H.S. Irwin \& Barneby & Leg. Cesalpinoideae & 1 \\
\hline 20 & Desmanthus virgatus (L.) Willd. & Leg. Mimosoideae & 18 & 49 & Senna obtusifolia (L.) H.S. Irwin \& Barneby & Leg. Cesalpinoideae & 20 \\
\hline 21 & Desmodium sp. & Leg. Faboideae & 3 & 50 & Senna occidentalis (L.) Link & Leg. Cesalpinoideae & 2 \\
\hline 22 & Desmodium molle (Vahl) DC & Leg. Faboideae & 4 & 51 & Sida sp. 1 & Malvaceae & 21 \\
\hline 23 & Diodia teres Walt. & Rubiaceae & 3 & 52 & Sida sp. 2 & Malvaceae & 18 \\
\hline 24 & Euphorbia hirta L. & Euphorbiaceae & 1 & 53 & Sida cordifolia $\mathrm{L}$. & Malvaceae & 1 \\
\hline 25 & Euphorbia hyssopifolia L. & Euphorbiaceae & 25 & 54 & Solanum agrarium Sendt. & Solanaceae & 8 \\
\hline 26 & Evolvulus ovatus Fem. & Convolvulaceae & 16 & 55 & Turnera clnuifolia L. & Tumeraceae & 15 \\
\hline 27 & Froelichia lanata Moench. & Amaranthaceae & 9 & 56 & Waltheria sp. 1 & Sterculiaceae & 4 \\
\hline 28 & Heliotropium claussenii DC & Boraginaceae & 2 & 57 & Waltheria sp. 2 & Sterculiaceae & 5 \\
\hline 29 & Herissantia crispa (L.) Briz. & Malvaceae & 75 & 58 & Waltheria indica $\mathrm{L}$. & Sterculiaceae & 56 \\
\hline
\end{tabular}


Table 2 - Weeds (numbers corresponding to order numbers in Table 1) in the plots

\begin{tabular}{|c|c|c|c|c|c|}
\hline \multirow{2}{*}{ Plots } & \multicolumn{5}{|c|}{ Blocks } \\
\hline & 1 & 2 & 3 & 4 & 5 \\
\hline 1 & $\begin{array}{l}7,26,27,2932,40, \\
41,58\end{array}$ & $\begin{array}{l}1,3,7,10,11,32,34 \\
36,40,41,58\end{array}$ & $\begin{array}{l}1,3,7,10,29,32,34, \\
38,40,41,54\end{array}$ & $\begin{array}{l}2,3,6,7,18,29,32 \\
33,34,40,41,43,54\end{array}$ & $\begin{array}{l}3,6,7,11,20,23,29 \\
33,40,41,43,58\end{array}$ \\
\hline 2 & $3,6,7,40,41,54,58$ & $1,3,10,40,41,43$ & $\begin{array}{l}3,5,10,11,14,27,29, \\
32,33,34,40,41,44, \\
51,52\end{array}$ & $\begin{array}{l}1,3,6,9,11,25,27 \\
29,32,40,41\end{array}$ & $\begin{array}{l}3,6,7,9,10,11,12 \\
19,25,27,32,41,58\end{array}$ \\
\hline 3 & $\begin{array}{l}3,11,17,20,32,33 \\
40,41,58\end{array}$ & $\begin{array}{l}3,17,25,28,29,32 \\
33,34,40,41,49,58\end{array}$ & $\begin{array}{l}1,3,9,10,29,31,32 \\
33,34,40,41,52,58\end{array}$ & $\begin{array}{l}1,3,6,10,14,29,32 \\
33,40,41,58\end{array}$ & $\begin{array}{l}1,3,6,7,14,19,20 \\
21,29,32,40,41,54\end{array}$ \\
\hline 4 & $\begin{array}{l}3,7,29,32,33,40,49 \\
58\end{array}$ & $\begin{array}{l}3,6,19,32,33,40,41 \\
49,52,58\end{array}$ & $\begin{array}{l}3,10,15,25,29,32 \\
40,41,49,58\end{array}$ & $\begin{array}{l}3,6,7,10,15,25,29, \\
32,34,38,40,41,42, \\
51,55,58\end{array}$ & $\begin{array}{l}3,6,7,14,19,25,29 \\
32,40,44\end{array}$ \\
\hline 5 & $3,16,32,40,44,58$ & $\begin{array}{l}1,10,27,29,32,40 \\
58\end{array}$ & $\begin{array}{l}3,6,7,10,29,32,34 \\
40,41,51\end{array}$ & $\begin{array}{l}1,3,6,9,10,18,19 \\
25,29,40,41,51,57\end{array}$ & $\begin{array}{l}3,7,10,25,29,32,40 \\
41,57\end{array}$ \\
\hline 6 & $\begin{array}{l}1,3,10,29,32,33,34 \\
40,41,58\end{array}$ & $\begin{array}{l}3,5,6,29,32,33,41, \\
58\end{array}$ & $\begin{array}{l}3,10,29,32,40,41, \\
58\end{array}$ & $\begin{array}{l}3,6,7,9,10,29,32 \\
40,41,49,55\end{array}$ & $\begin{array}{l}3,7,10,11,15,18,26 \\
32,39,41,49,58\end{array}$ \\
\hline 7 & $\begin{array}{l}3,6,10,25,32,34,40, \\
41,58\end{array}$ & $\begin{array}{l}3,6,10,15,29,32,41, \\
51,52,58\end{array}$ & $\begin{array}{l}2,3,10,11,15,26 \\
29,32,40,41,58\end{array}$ & $\begin{array}{l}3,6,10,11,25,2932 \\
40,41,45,55,56\end{array}$ & $\begin{array}{l}3,7,10,11,25,26,29 \\
32,40,41,50,56\end{array}$ \\
\hline 8 & $\begin{array}{l}1,3,10,11,20,33,34 \\
40\end{array}$ & $\begin{array}{l}3,6,10,29,32,40,41 \\
52,58\end{array}$ & $\begin{array}{l}3,5,6,10,11,15,26 \\
29,32,40,41,58\end{array}$ & $\begin{array}{l}1,3,6,10,15,25,29 \\
32,33,40,41,49,54\end{array}$ & $\begin{array}{l}3,7,11,12,19,29,32 \\
40,41,49,54,56,58\end{array}$ \\
\hline 9 & $\begin{array}{l}1,3,6,10,11,22,32 \\
34,40,41,52,57\end{array}$ & $\begin{array}{l}1,3,6,10,15,19,32 \\
33,40,44,48,58\end{array}$ & $\begin{array}{l}1,7,19,25,29,32,33 \\
40,41,58\end{array}$ & $\begin{array}{l}1,3,10,11,17,32,33 \\
40,41,49,57,58\end{array}$ & $\begin{array}{l}3,8,10,11,20,29,32, \\
33,38,40,51\end{array}$ \\
\hline 10 & $\begin{array}{l}10,11,15,29,32,33 \\
40,41,55,58\end{array}$ & $1,3,10,17,33,40,42$ & $\begin{array}{l}3,7,9,10,11,15,29 \\
32,38,40,41,58\end{array}$ & $\begin{array}{l}1,3,10,14,15,21,29, \\
32,33,34,40,41,42, \\
44,55\end{array}$ & $\begin{array}{l}3,6,7,10,11,33,35 \\
40,41,44,49,55,58\end{array}$ \\
\hline 11 & $\begin{array}{l}3,10,11,20,26,27 \\
29,32,34,36,40,41 \\
45,49\end{array}$ & $\begin{array}{l}3,4,6,7,10,25,32 \\
34,40,41,46,58\end{array}$ & $\begin{array}{l}1,3,10,11,19,20,21, \\
25,26,27,29,32,40, \\
41,44,51,52,58\end{array}$ & $\begin{array}{l}3,6,7,11,19,29,32 \\
33,40,41,51,55,58\end{array}$ & $\begin{array}{l}3,7,11,17,25,32,33 \\
34,39,40,41,49,58\end{array}$ \\
\hline 12 & $\begin{array}{l}6,11,19,20,23,25 \\
29,32,33,40,41,58\end{array}$ & $\begin{array}{l}1,3,10,19,20,26,29 \\
32,36,40,41,51,52 \\
58\end{array}$ & $\begin{array}{l}2,3,7,10,25,32,40 \\
41,58\end{array}$ & $\begin{array}{l}3,7,10,11,14,19,29, \\
32,33,40,41,49,51, \\
58\end{array}$ & $\begin{array}{l}1,3,11,15,25,29,32 \\
33,34,40,41,51,58\end{array}$ \\
\hline 13 & $\begin{array}{l}1,9,10,15,25,26,28 \\
29,32,33,40,41\end{array}$ & $\begin{array}{l}3,10,11,19,20,27 \\
29,32,33,34,41,49 \\
51,52,55\end{array}$ & $\begin{array}{l}1,3,6,11,19,23,29 \\
40,41,49,51\end{array}$ & $\begin{array}{l}3,6,7,9,10,14,17 \\
22,29,32,33,40,58\end{array}$ & $\begin{array}{l}1,3,7,11,29,32,40 \\
47,51,58\end{array}$ \\
\hline 14 & $\begin{array}{l}9,10,26,29,32,40, \\
41\end{array}$ & $\begin{array}{l}3,29,33,41,49,52, \\
58\end{array}$ & $\begin{array}{l}6,10,20,24,26,29 \\
32,40,41,52,54\end{array}$ & $\begin{array}{l}3,6,7,10,16,22,29 \\
32,40,41,52\end{array}$ & $\begin{array}{l}1,3,6,11,29,32,40 \\
41,49,51\end{array}$ \\
\hline 15 & $\begin{array}{l}7,10,29,32,33,40 \\
41\end{array}$ & $3,10,15,32,33,40$ & $\begin{array}{l}3,10,29,32,33,40, \\
41\end{array}$ & $\begin{array}{l}3,11,14,19,20,22, \\
25,29,40,41\end{array}$ & $\begin{array}{l}1,3,11,14,25,29,32 \\
40,41,49,58\end{array}$ \\
\hline 16 & $\begin{array}{l}10,17,29,32,33,40, \\
41,55\end{array}$ & $1,3,7,29,32,33,41$ & $\begin{array}{l}3,5,10,19,29,32,33, \\
40,52,54,58\end{array}$ & $\begin{array}{l}3,7,10,26,29,32,40, \\
41\end{array}$ & $\begin{array}{l}1,3,26,29,32,40,41, \\
49,56,58\end{array}$ \\
\hline 17 & $\begin{array}{l}3,10,19,20,29,32 \\
36,39,40,41,43\end{array}$ & $\begin{array}{l}10,11,20,26,32,40 \\
41,51,58\end{array}$ & $\begin{array}{l}3,6,10,20,29,32,40 \\
41,51,52,58\end{array}$ & $\begin{array}{l}1,3,11,14,25,26,29 \\
32,41\end{array}$ & $\begin{array}{l}1,3,7,11,29,32,34 \\
40,41,49,53,58\end{array}$ \\
\hline 18 & $\begin{array}{l}17,29,32,33,36,40 \\
41,42,52\end{array}$ & $\begin{array}{l}1,3,7,9,20,29,32 \\
33,40,41,52\end{array}$ & $\begin{array}{l}1,3,10,11,20,29,32, \\
40,41,58\end{array}$ & $\begin{array}{l}3,7,11,14,29,32,33 \\
34,39,40,41,58\end{array}$ & $\begin{array}{l}1,3,7,11,14,19,27 \\
29,32,41,58\end{array}$ \\
\hline 19 & $\begin{array}{l}10,12,29,32,33,40 \\
41,46,55,57\end{array}$ & $\begin{array}{l}5,11,20,30,32,33 \\
40,41,52\end{array}$ & $\begin{array}{l}9,11,17,26,29,32, \\
40,41,52,58\end{array}$ & $\begin{array}{l}3,11,17,25,32,36 \\
40,41,51,55\end{array}$ & $\begin{array}{l}1,7,11,29,30,33,40 \\
41,51\end{array}$ \\
\hline 20 & $\begin{array}{l}11,13,32,40,41,51, \\
55,58\end{array}$ & $\begin{array}{l}1,4,25,29,32,33,40 \\
41,51,55\end{array}$ & $\begin{array}{l}17,25,29,32,33,40 \\
41,58\end{array}$ & $\begin{array}{l}1,5,32,37,40,41,51, \\
55\end{array}$ & $\begin{array}{l}3,7,33,33,37,41,51, \\
55\end{array}$ \\
\hline
\end{tabular}

the distribution of weeds was obviously obtained based on the data collected in the $0.5 \mathrm{~m}^{2}$ area under the canopy of each custard apple tree and not in the entire experimental area, when the experiment was installed.
In large areas, soil, rainfall precipitation and topography gradients, among other environmental factors, are important for species richness and distribution (Augustine, 2003). Rainfall precipitation plays an 
important role in research, when the floristic composition inventory is computed for several periods of the same year (Yanagizawa \& Maimoni-Rodella, 1999) or for the same season in several years (Brown, 2003), and certainly for experiments involving irrigation. Furthermore, a great number of cultural practices can influence the diversity and composition of the weed community (Hyvönen \& Salonen, 2002). During rainy seasons, greater richness of weeds usually occurs (Yanagizawa \& Maimoni-Rodella, 1999). Species composition depends especially on the amount and season of the opening rains to stimulate germination (Brown, 2003). The weed seed bank was not quantified during the time when the experiment was carried out. In spite of the importance of such quantification to explain the results obtained in the present work, it has been observed that emerging weed flora is difficult to be evaluated (Voll et al., 2003). Reliable predictions of the emerging flora cannot be obtained based on the number of seeds in the soil seed bank (Zhang et al., 1998). A potential for the occurrence of estimation errors will persist, depending on the environmental conditions which affect seed dormancy and germination (Fenner, 1985).

Based on the experiment upon which this work was based, with all the plants receiving approximately the same amount of water, it seems reasonable to assume that other soil characteristics, besides moisture content, were more important in determining weed species richness and distribution, in the "moist islands" that formed under microsprinkling irrigation. For example, Borreria verticilata and Centrosema brasilianum, which occurred at frequencies of $37 \%$ and $36 \%$, respectively (Table 1 ), were observed in all five blocks, but their occurrence was greater in the last blocks. This heterogeneity in occurrence was perhaps associated with the correlation between weed densities and some physical and chemical characteristics of the soil, including clay or sand contents, $\mathrm{pH}$, nitrogen, phosphorus, organic matter, etc. (Britton et al., 2003; Walter et al., 2002). This is a complex correlation, since it varies with the environment, i.e., with the area evaluated and with the year of study (Walter et al., 2002).
No differences between progenies were observed with regard to the percentages of different weed species under them (Table 3). However, differences were observed between fresh and dry matter masses of weeds associated with the progenies (Table 3). The option was made for including fresh and dry mass data, since custard apple tree behavior was different regarding these two characteristics. The greatest means for these characteristics were observed in progeny A 1 . With regard to fresh matter, progeny A1 did not differ from progenies A2, A3, A4, FE1, FE5, and FJ2. With respect to dry matter, progeny A1 did not differ from progenies A2, A3, FE5, and FJ2. The differences between progenies with regard to fresh and dry matter mass of weeds must be related to characteristics of the progenies themselves, but are also related to the number and type of weed species that grow under them.

Different crops (Samra et al., 1999; Seavers \& Wright, 1999; Souza et al., 2003; Yanagizawa \& Maimoni-Rodella, 1999) and different cultivars of the same crop (Rossi et al., 1996; Seavers \& Wright, 1999) are capable of influencing the composition and growth of weeds. In cereals, the competitive ability against weeds is associated with greater total leaf area, resistance to tiller loss under competitive pressure, greater plant height, structure of the above-ground part of the plant and development. The suppressive effect of perennial plants on weeds is frequently attributed to shading by trees (Souza et al., 2003; Yanagizawa \& Maimoni-Rodella, 1999). In fact, there are evidences that shading reduces growth in grasses (Kumar et al., 2001). A reduction in grass productivity occurs with the expansion of the canopies of trees grown in association with them and vice versa, i.e., as the trees are pruned, grass yield increases (Kumar et al., 2001). However, other factors are involved. Despite having an "open" canopy, compared to two other tree species, Senna siamea has shown a strong depressive effect on the herbaceous canopy under it, probably due to its greater mass of fine roots (Harmand et al., 2003). In spite of the potential importance of crop plant architecture for weed control, specially with respect to shading effects, evaluations of luminosity under the canopy of custard apple trees were not made 
in the present work. Finally, the development of allelopathic cultivars must not be forgotten, as a promising weed management strategy that has received increasing international attention (Wu et al., 1999). Different custard apple tree progenies could influence weed growth differently under the canopy, by means of allelopathy.

Thus, a great number of traits associated with custard apple tree progenies must influence the weeds associated with them. Canopy diameter was largest in progeny FE4, which only differed from that of progenies A2, A5, FE5, and SM1 (Table 3). This characteristic must be relevant for competition against weeds, since dry matter mass in the aboveground part of the progeny showing the lagest mean canopy diameter (FE4) did not differ from the progeny in which the weeds showed the smallest dry mass in the above-ground part (SM8). In addition, one of the progenies showing the smallest canopy diameter (A2) also showed one of the greatest weed dry matter masses. The coefficient of linear correlation estimates $(r)$ between canopy diameter and weed frequency plus the fresh and dry masses of these plants were -0.31, -0.32 and -0.39 , respectively, all significant at $1 \%$ probability. This fact suggests the importance of increasing custard apple tree canopy diameter reducing weeds under them, since the correlations were negative. However, it must be kept in mind that the $r$ value does hot always establish a cause and effect relationship between two variables (Gomez \& Gomez, 1984). On the other hand, in addition to canopy diameter, other characteristics related to the canopy must be involved, such as branch distribution, number of leaves per plant, etc. Currently there has been a great interest in the development of cultivars capable of competing more efficiently against weeds, in order to reduce the use of herbicides (Seavers \& Wright, 1999). In coffee plants (Coffea arabica), the continued use of

Table 3 - Frequency (number of weed species/total of weed species in the experiment area) and fresh and dry matter mass in the above-ground part of weeds, root collar and canopy diameters, and leaf area of custard apple tree progenies ${ }^{1 /}$

\begin{tabular}{|c|c|c|c|c|c|c|c|}
\hline \multirow[b]{2}{*}{ Progenies } & \multicolumn{4}{|c|}{ Weeds under the canopy of progenies } & \multicolumn{3}{|c|}{ Custard apple tree progenies } \\
\hline & $\begin{array}{c}\text { Frequency } \\
(\%)\end{array}$ & $\begin{array}{l}\text { Frequency } \\
(\arcsin \sqrt{ } \text { p) }\end{array}$ & $\begin{array}{l}\text { Fresh matter } \\
\qquad\left(\mathrm{g} \mathrm{m}^{-2}\right)\end{array}$ & $\begin{array}{c}\text { Dry matter } \\
\left(\mathrm{g} \mathrm{m}^{-2}\right)\end{array}$ & $\begin{array}{c}\text { Canopy } \\
\text { diameter }(\mathrm{m})\end{array}$ & $\begin{array}{c}\text { Root collar } \\
\text { diameter }(\mathrm{cm})\end{array}$ & $\begin{array}{c}\text { Leaf area } \\
\left(\mathrm{cm}^{2}\right)\end{array}$ \\
\hline $\mathrm{A} 1$ & 19.3 & 26.1 & $498.5 \mathrm{a}$ & $164.3 \mathrm{a}$ & $2.47 \mathrm{ab}$ & 70.2 & 39.5 \\
\hline A2 & 17.6 & 24.8 & $391.5 \mathrm{ab}$ & $134.3 \mathrm{ab}$ & $2.43 \mathrm{~b}$ & 77.3 & 41.9 \\
\hline $\mathrm{A} 3$ & 19.0 & 25.8 & $389.4 \mathrm{ab}$ & 119.7 abcde & $2.57 \mathrm{ab}$ & 75.4 & 42.4 \\
\hline A4 & 18.6 & 25.6 & $258.5 \mathrm{ab}$ & 74.0 bcde & $2.63 \mathrm{ab}$ & 77.6 & 42.8 \\
\hline A5 & 17.6 & 24.8 & $177.2 \mathrm{bc}$ & 69.1 bcde & $2.45 \mathrm{~b}$ & 76.9 & 40.3 \\
\hline A6 & 16.9 & 24.3 & $228.0 \mathrm{bc}$ & 71.4 bcde & $2.61 \mathrm{ab}$ & 78.4 & 40.0 \\
\hline FE1 & 20.0 & 26.6 & $304.3 \mathrm{ab}$ & 99.5 abcde & $2.49 \mathrm{ab}$ & 77.7 & 44.3 \\
\hline FE3 & 17.9 & 25.0 & $153.1 \mathrm{bc}$ & 65.1 bcde & $2.52 \mathrm{ab}$ & 74.0 & 41.4 \\
\hline FE4 & 16.2 & $\begin{array}{ll}23.7 \\
23.7\end{array}$ & $188.2 \mathrm{bc}$ & 60.3 bcde & $2.78 \mathrm{a}$ & $\begin{array}{ll}79.9 \\
79\end{array}$ & 44.1 \\
\hline FE5 & 19.3 & 26.4 & $337.5 \mathrm{ab}$ & $124.8 \mathrm{abcd}$ & $2.39 \mathrm{~b}$ & 74.0 & 40.6 \\
\hline FJ1 & 19.7 & 26.4 & $206.7 \mathrm{bc}$ & 81.0 bcde & $2.60 \mathrm{ab}$ & 74.9 & 41.2 \\
\hline FJ2 & 15.9 & 23.5 & $386.0 \mathrm{ab}$ & $131.4 \mathrm{abc}$ & $2.63 \mathrm{ab}$ & 78.0 & 42.7 \\
\hline JG1 & 20.0 & 26.6 & $145.9 \mathrm{c}$ & $46.7 \mathrm{de}$ & $2.52 \mathrm{ab}$ & 79.8 & 41.7 \\
\hline JG2 & 20.0 & 26.6 & $168.0 \mathrm{bc}$ & $51.5 \mathrm{cde}$ & $2.60 \mathrm{ab}$ & 78.2 & 40.7 \\
\hline JG3 & 17.9 & 25.0 & $180.1 \mathrm{bc}$ & 63.0 bcde & $2.62 \mathrm{ab}$ & 80.4 & 42.2 \\
\hline JG4 & 18.9 & 25.8 & $214.3 \mathrm{bc}$ & 66.9 bcde & $2.65 \mathrm{ab}$ & 81.5 & 40.2 \\
\hline SM1 & 17.6 & 24.8 & $248.5 b c$ & $76.5 \mathrm{bcde}$ & $2.41 \mathrm{~b}$ & 82.2 & 41.7 \\
\hline SM3 & 17.6 & 24.8 & $179.7 \mathrm{bc}$ & 58.4 bcde & $2.51 \mathrm{ab}$ & 76.4 & 38.9 \\
\hline SM7 & 17.2 & 24.5 & $174.5 \mathrm{bc}$ & $47.3 \mathrm{de}$ & $2.63 \mathrm{ab}$ & 77.8 & 37.7 \\
\hline SM8 & 16.9 & 24.3 & $154.7 \mathrm{bc}$ & $38.2 \mathrm{e}$ & $2.55 \mathrm{ab}$ & 74.1 & 43.3 \\
\hline CV (\%) & - & 12 & 43 & 43 & 6 & 8 & 10 \\
\hline
\end{tabular}

${ }^{1 /}$ Means followed by a common letter are not different among themselves at $5 \%$ probability by Tukey test. 
preemergence herbicides, in addition to reducing the soil organic matter content, has caused the formation of crusts on the soil surface (Alcântara \& Ferreira, 2000). No differences were observed between progenies with respect to root collar diameter and leaf area (Table 3 ). With regard to root colar diameter, the coefficient of linear correlation estimates with weed frequency plus the fresh and dry masses of these plants were -0.21, -0.41 , and -0.46 , respectively, and were all significant at $1 \%$ probability. It does not seem very likely that root collar diameter would have an influence on these weed characteristics. The relationship between root collar diameter and canopy diameter could explain these correlations. In fact, the $r$ value between these two characteristics (0.34) was positive and significant at $1 \%$ probability. With regard to leaf area, the coefficient of linear correlation estimates with weed frequency plus the fresh and dry masses of these plants were -0.06, 0.08 , and 0.46 , respectively, all non-significant at $5 \%$ probability. Custard apple tree leaf area must be important for weed reduction as long as the plant area is considered as a whole; this was not the case in the present work, where only the areas of individual leaves were measured. Progeny plant height was not evaluated because plant pruning has been performed to maintain them with a height around $2.0 \mathrm{~m}$.

With regard to the number and species of weeds that grow under a certain custard apple tree, interspecific and intraspecific interactions must occur influencing the composition and growth of weeds as a whole, which, in turn, must depend on other environmental factors (Britton et al., 2003). Such interactions can facilitate or discourage the development of certain weed species. This could help explain the differences in weed growth under some progenies (Table 3 ). The "moist island" around the stem of each custard apple tree can be considered as an "optimal environment" as compared to the environment in the rest of the area (nonirrigated). In this case, the competition intensity between weeds would be much greater, since there would be more biomass and the interactions would be more frequent (Grime, 1973). However, arguments exist according to which competition intensity is equally high across productivity gradients. In non-productive habitats, the interactions between plants occur especially below the ground level, while in productive environments competition above the ground level is predominant (Newman, 1973). Under aridity conditions, the most recent information has demonstrated that no differences exist in competition intensity between annual plants, growing or not under shrubs (Tielbörger \& Kadmon, 2000).

\section{LITERATURE CITED}

AGUILAR, V.; STAVER, C.; MILBERG, P. Weed vegetation response to chemical and manual selective ground cover management in a shaded coffee plantation. Weed Research, v. 43, p. 68-75, 2003.

ALCÂNTARA, E. N.; FERREIRA, M. M. Efeitos de métodos de controle de plantas daninhas na cultura do cafeeiro (Coffea arabica L.) sobre a qualidade física do solo. Rev. Bras. Ci. Solo, v. 24, p. 711-721, 2000.

AUGUSTINE, D. J. Spatial heterogeneity in the herbaceous layer of a semi-arid savanna ecosystem. Plant Ecol., v. 167, p. 319-332, 2003.

BRITTON, A. et al. The influence of soil-type, drought and nitrogen addition on interactions between Calluna vulgaris and Deschampsia flexuosa: implications for heathland regeneration. Plant Ecol., v. 166, p. 93-105, 2003.

BROWN, G. Species richness, diversity and biomass production of desert annuals in an ungrazed Rhantherium epapposum community over three seasons in Kuwait. Plant Ecol., v. 165, p. 53-68, 2003.

CARMO FILHO, F.; OLIVEIRA, O. F. Mossoró: um município do semi-árido nordestino. Mossoró, Fundação Guimarães Duque/ESAM, 1989. 62 p. (Coleção Mossoroense, Série B, 672).

CARVALHO, J. E. B. et al. Influência das épocas de controle das plantas daninhas na produção de laranja 'Pera'. Planta Daninha, v. 11, p. 49-54, 1993.

DeFRANK, J.; CLEMENT, C. R. Weed control in pejibaye heart of palm plantations in Hawaii. HortScience, v. 30, p. 1215-1216, 1995.

EMPRESA BRASILEIRA DE PESQUISA AGROPECUÁRIA - EMBRAPA. Centro Nacional de Pesquisa do Solo. Sistema brasileiro de classificação de solos. Brasília: Serviço de Produção de Informação, 1999. 412 p.

FAO. Soil map of the world; revised legend. Rome: UNESCO, 1988. 119 p. 
FENNER, M. Seed ecology. New York: Chapman \& Hall, 1985. $325 \mathrm{p}$.

GOMEZ, K. A.; GOMEZ, A. A. Statistical procedures for agricultural research. New York: John Wiley, 1984. 680 p.

GRIME, J. P. Competitive exclusion in herbaceous vegetation. Nature, v. 242, p. 344-347, 1973.

HARMAND, J. M.; DONFACK, P.; NJITI, C. F. Treeroot systems and herbaceous species-characteristics under tree species introduced into grazing lands in subhumid Cameroon. Agrofor. Systems, v. 59, p. 131-140, 2003.

HYVÖNEN, T.; SALONEN, J. Weed species diversity and community composition in cropping practices at two intensity levels - a six-year experiment. Plant Ecol., v. 159, p. 73-81, 2002.

KUMAR, B. M.; GEORGE, S. J.; SURESH, T. K. Fodder grass productivity and soil fertility changes under four grass + tree associations in Kerala, India. Agrofor. Systems, v. 52, p. 91-106, 2001.

NEWMAN, E. I. Competition and diversity in herbaceous vegetation. Nature, v. 244, p. 310-311, 1973.

RIBEIRO JÚNIOR, J. I. Análises estatísticas no SAEG. Viçosa: Universidade Federal de Viçosa, 2001. 301 p.

RONCHI, C. P. et al. Acúmulo de nutrientes pelo cafeeiro sob interferência de plantas daninhas. Planta Daninha, v. 21, p. 219-227, 2003.

ROSSI, I. H. et al. Interferência das plantas daninhas sobre algumas características agronômicas e a produtividade de sete cultivares de milho. Planta Daninha, v. 14, p. 134-148, 1996.

SAMRA, J. S.; VISHWANATHAM, M. K.; SHARMA, A. R. Biomass production of trees and grasses in a silvopasture system on marginal lands of Doon Valley of north-west India. 2. Performance of grass species. Agrofor. Systems, v. 46, p. 197-212, 1999.

SANTA-CECÍLIA, L. V. C.; SOUZA, B.; SOUZA, M. Levantamento de plantas invasoras, hospedeiras da cochonilha-da-raíz Pseudococcus comstocki (Kuwana, 1902) (Homoptera: Pseudococcidae) em um viveiro de matrizes de citros. R. Bras. Frutic., v. 19, p. 377-379, 1997.

SÃO JOSÉ, A. R. et al. (Eds.). Anonáceas; produção e mercado. Vitória da Conquista: Universidade Estadual do Sudoeste da Bahia, 1997. 308 p.
SENARATHNE, S. H. S.; SAMARAJEEWA, A. D.; PERERA, K. C. P. Comparison of different weed management systems and their effects on yield of coconut plantations in Sri Lanka. Weed Biol. Manag., v. 3, p. 158161, 2003.

SEAVERS, G. P.; WRIGHT, K. J. Crop canopy development and structure influence weed suppression. Weed Res., v. 39, p. 319-328, 1999.

SOUZA, L. S. A.; SILVA, J. F.; SOUZA, M. D. B. Composição florística de plantas daninhas em agrossistemas de cupuazeiro (Theobroma grandiflorum) e pupunheira (Bactris gasipaes). Planta Daninha, v. 21, p. 249-255, 2003.

TIELBÖRGER, K.; KADMON, R. Indirect effects in a desert plant community: is competition among annuals more intense under shrub canopies? Plant Ecol., v. 150, p. 53-63, 2000 .

TOLEDO, R. E. B. et tal. Efeitos da faixa de controle do capim-braquiária (Brachiaria decumbens) no desenvolvimento inicial de plantas de eucalipto. Planta Daninha, v. 18, p. 383-393, 2000a.

TOLEDO, R. E. B. et al. Efeitos de períodos de controle de plantas daninhas sobre o desenvolvimento inicial de plantas de eucalipto. Planta Daninha, v. 18, p. 395-404, 2000 b.

VOLL, E. et al. Amostragem do banco de semente e flora emergente de plantas daninhas. Pesq. Agropec. Bras., Brasília, v. 38, n. 2, p. 211-218, 2003.

WALTER, A. M.; CHRISTENSEN, S.; SIMMELSGAARD, S. E. Spatial correlation between weed species densities and soil properties. Weed Res., v. 42, p. 26-38, 2002.

WU, H. et al. Crop cultivars with allelopathic capability. Weed Res., v. 39, p. 171-180, 1999.

YANAGIZAWA, Y. A. N. P.; MAIMONI-RODELLA, R. C. S. Composição florística e estrutura da comunidade de plantas do estrato herbáceo em áreas de cultivo de árvores frutíferas. Planta Daninha, v. 17, p. 459-468, 1999.

ZAR, J. H. Biostatistical analysis. 4.ed. Upper Saddle River: Prentice Hall, 1999. 663 p.

ZHANG, J. et al. Dependence of seed flora on the active soil seed bank. Weed Res., v. 38, n. 1, p. 143-152, 1998. 